\title{
A REVIEW OF THE IMPACTS AND MANAGEMENT OF OILY SLUDGE IN THE OIL AND GAS INDUSTRY
}

\author{
Francis Atta Kuranchie ${ }^{1}$, Francis Attiogbe ${ }^{2}$, Ama Mbeaba Quarshie ${ }^{3}$ \\ ${ }^{1}$ Lecturer, University of Energy and Natural Resources, Department of Energy and Environmental Engineering, \\ Sunyani, Ghana and Adjunct Lecturer, Edith Cowan University, School of Engineering, Joondalup, Australia \\ ${ }^{2}$ Senior Lecturer and Head of Department, University of Energy and Natural Resources, \\ Department of Energy and Environmental Engineering, Sunyani, Ghana \\ ${ }^{3} \mathrm{PhD}$ Candidate, University of Energy and Natural Resources, \\ Department of Energy and Environmental Engineering, Sunyani, Ghana
}

\begin{abstract}
Oil and gas extraction has become indispensable so as to meet the energy demands of society. The extraction and refinery of these resources cannot be done without the generation of wastes. The wastes generated such as oily sludge are mostly harmful to the environment and human health and some are also hazardous in nature. It has the risk of preventing vegetation growth, leaching of heavy metals into aquifer and water bodies that could cause contamination and affect aquatic and human life. The sustainable and environmental friendly method of management of oily sludge from the oil and gas industry is still a major challenge confronting stakeholders in the industry. This paper is a mini-review of the potential impacts on the environment and human risks associated with oily sludge and the current management practices employed in the industry. It also looks into the future concerning oily sludge management by collection and reviewing of a wide range of journal papers and industry databases relevant to the subject. The work concludes that enough attention has been drawn to some technologies for oily sludge management. However, in order to minimize the quantities of oily sludge and to make it more environmentally friendly, recovery is viewed more positively over other methods since it is capable of reducing the volume of oily sludge and by extension reduce the treatment cost.
\end{abstract}

Keywords: Oily sludge, hydrocarbon, waste management, oil and gas industry, recovery and impacts on the environment.

\section{INTRODUCTION}

Global oil discoveries have greatly increased in recent years but the spontaneous finds in the world in 2009 , led to a major boost in the petroleum industry irrespective of the downward trend in the price of the main product and the credit crunch in global economies. Petroleum products are indeed the primary products that are meeting the energy needs of the global economies. The natural reserve of this main petroleum hydrocarbon is enormous though exhaustible. The demand for products of the oil and gas industry has been on an increasing trajectory globally. [8] Has estimated that the demand for oil and gas products is expected to hit $37 \%$ by the year 2035 and that the driving force behind this increase is worldwide population growth. This will come with other numerous environmental incidents such as oil spillage (Helmy and Kardena, 2015). The motivation behind meeting global oil and gas demands has thus generated volumes of wastes which has become a nuisance not only to the physical environment but also to human health.

The extraction and subsequent processing of this petroleum products like many other products does not occur without the generation of wastes. One such waste from this industry is the oily or petroleum sludge. According to Oudenhover et al. (2013), oily sludge is generated from both upstream and downstream operations in the petroleum industry and it generates a large amount of oily waste. While the upstream operations include the processes of extraction, transporting and storage of crude oil, the downstream operation refers to the refinery processes associated with the crude oil. Fig-1 below shows the various stages in the oil production and refining where oily sludges are produced. 


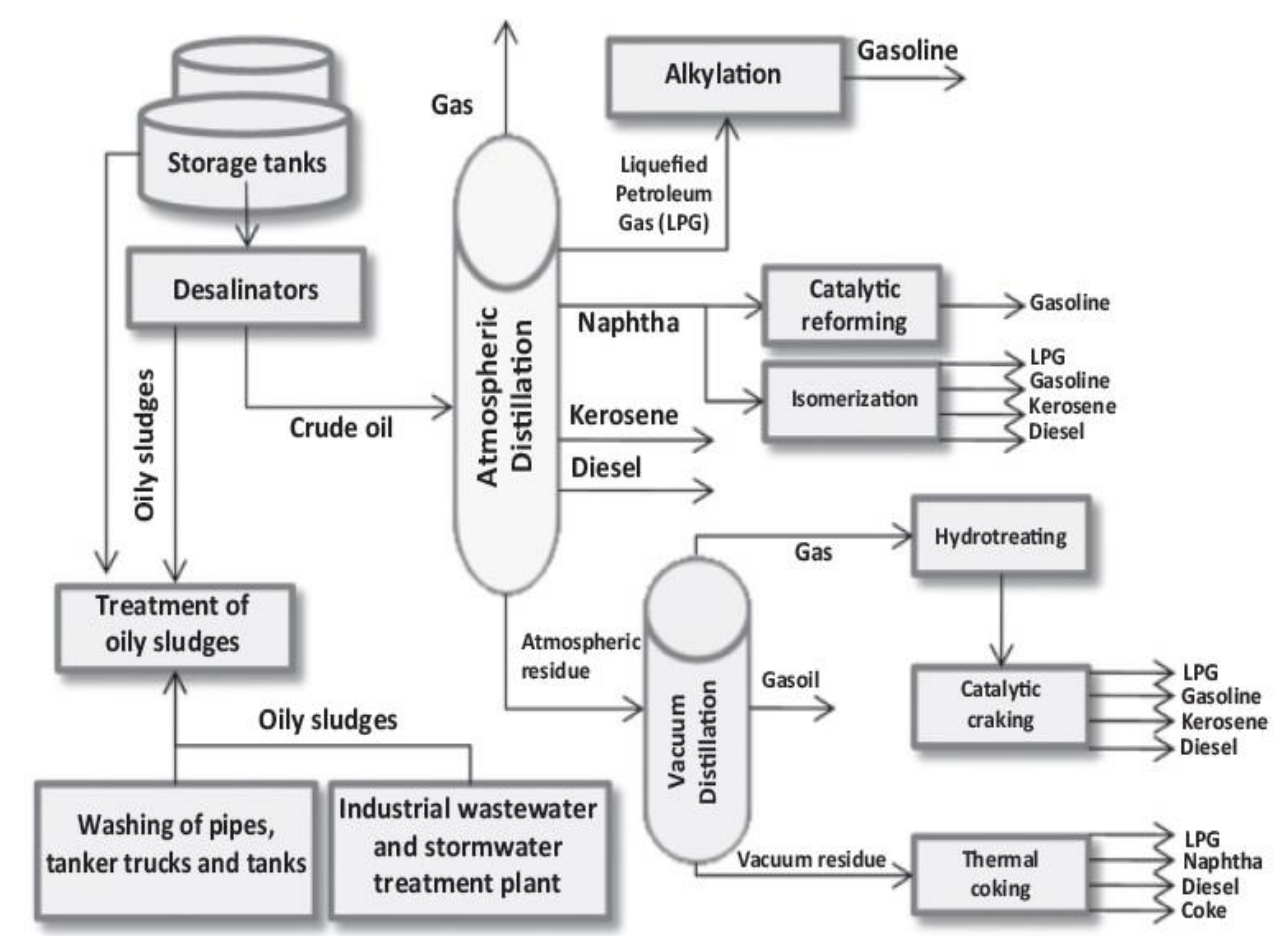

Fig-1: Oil Extraction Processes and the Stages of Oily Sludge Production [11].

Oily sludge is a complex emulsion of various petroleum hydrocarbons (PHCs), water, heavy metals, and solid particles (Guangji et al, 2013). [6] extends this to include naturally occurring radioactive materials (NORM). [24] also contends that no unique formulae is required in estimating the composition of sludge since its physical, chemical and physio-chemical analyses are to be considered before an accurate composition and elements present can be assessed. [6] confirms this assertion and further noted that the composition of oily sludge is not certain as its make-up is dependent on a number of factors: the large diversity in the quality of crude oils, differences in the processes used for oil-water separation, leakage during industrial processes and it's mixing with the existing oily sludge. Other schools of thought have it that the composition of petroleum sludge includes oil in waste, water in oil emulsion and suspended solids [1]. Aromatic hydrocarbon, poly aromatic hydrocarbons and high total hydrocarbons contents also exist [5].

The high viscosity of oily sludge makes its hydration difficult as it comprises about $55.13 \%$ water,9.246\% sediment, $1.9173 \%$ asphaltenes, $10.514 \%$ wax and $23.19 \%$ of light hydrocarbons. It also has a high concentration of heavy metals such as vanadium (204 ppm), iron (0.6\%) and Nickle (506 ppm); thus, making it a hazardous waste (Kumar and Raj Mohan, 2013). [13], confirms this and included other compositions such as sand and fine-grained soil and water.

During production and processing of crude oil the sludge generated are usually accumulated in crude oil tanks, refinery product tanks, desalters and elsewhere. According to [6], if the oil content in sludge is more than $40 \%$, the oil is separated from the water and solids and then pumped back into the refinery process again while the water and sand are treated before disposal. On the other hand, if the oil content is less than $40 \%$, it is considered to contain low oil and will therefore be treated and disposed of. Treatment before disposal makes it less harmful to the environment. Methods like pyrolysis, freeze/thaw, incineration and microwave irradiation are commonly used in Iran but these are not efficient enough in those oil producing regions which generally have dry and hot climate and the process is also expensive. The freeze/thaw method in an extremely hot weather like the southern part of Iran can cost huge sums of money and energy, just to reach a freezing point. Thus, making the method not conducive in such regions with this climate conditions $[11,19]$.

According to (Helmy and Kardena, 2015), the oil sludge and produced water are the most abundant waste in the exploration and processing operation to date. [6], also contend that oily sludge is problematic for two reasons; first, it is considered as a hazardous waste due to its oil content and also the fact that it does not lend itself to easy disposal into landfills because it is classified as liquid. Since there are no better options for dealing with this waste it only continues to accumulate in large quantities.

Unfortunately, there is currently an estimated 9 billion tons of oily sludge on the planet. The volume continues to rise every minute due to extensive exploration and production of petroleum products. A million tons of sludge accumulate 
annually worldwide [12]. According to Van Oudenhover et al. 2013, for every 500 tons of crude oil processed a ton of petroleum sludge is produced. [23], re-affirm this by stating that the rate of accumulation of oily sludge in the environment is on the rise. The fact that petroleum sludge has hazardous components and also does not easily lend itself to traditional management methods but continues to accumulate in the environment makes it an important waste for consideration and this led to the review of this waste. This review therefore, aims at finding the composition of oily sludge, its generation capacities and volumes from the oil producing industries in terms of countries and its effects on the environment.

\section{METHODOLOGY}

Peer-review journals, Articles, Books, web pages and databases with relevant information on oil and gas wastes were carefully reviewed. Several studies were reviewed and compared with their reported volume of wastes and the management modes applied. Some of the relevant data that were useful for this work bothered on the meaning of oily sludge and how they are generated. Data on the volumes of oily sludge generated in some selected oil producing countries were computed by converting barrels of crude oil production in those countries into tons using the metric standard (i.e. 1 metric ton is approximately 7 barrels). Further, conversion of the tons of crude oil to tons of oily sludge was done based on the standard given by [23]. According to [23], a ton of petroleum sludge is produced

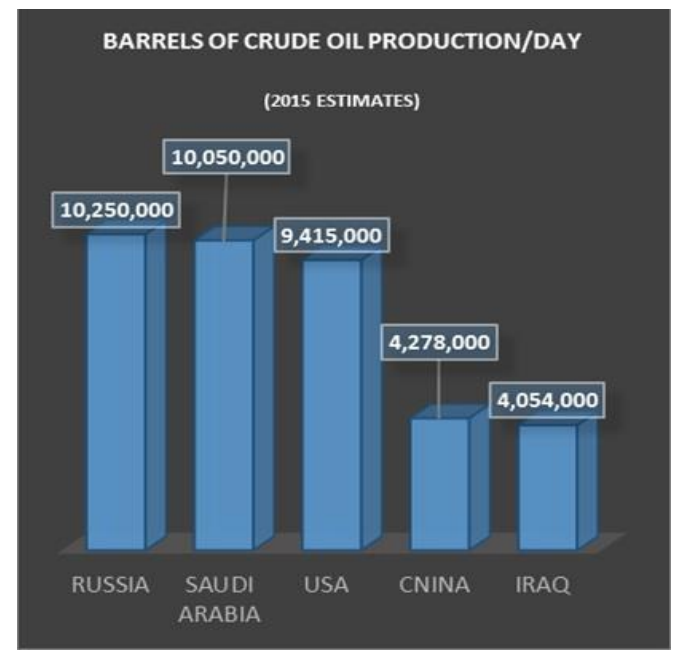

Fig-2a: Estimated World Highest Crude Oil Producing Countries for 2015 Information Adopted from the World Fact Book-Rank Order

Slovenia, Jordan, Morocco, Tajikistan and Taiwan are countries which produced the least barrels of crude oil daily in the world for the year 2015. Of the world five least daily crude oil producing countries; Taiwan, Tajikistan and Morocco produced 190,182 and 160 barrels respectively and generated $0.056,0.052$ and 0.046 metric tons of sludge respectively. Of the last five oil producing countries, Jordan and Slovenia produced the least oil with 22 and 5 barrels of from the processing of every 500 tons of crude oil. The results obtained from the conversions were then entered into the Microsoft excel spread sheet for the generation of bar charts for interpretation and analysis.

\section{RESULTS AND DISCUSSION}

\subsection{Volumes of Daily Oily Sludge Generation/Ton}

Crude oil production and the subsequent generation of sludge varies from country to country in the world. Overall 216 countries registered on the list of oil producing countries. This was published by the world fact book rank order. Of this, 101 produced some significant volumes of oily sludge. According to Van Oudenhover et al. 1995, every 500 tons of crude oil generates a ton of petroleum sludge. Of the top 5 world highest oil producing countries, Russia $(10,250,000$ barrels) was found to produce the highest crude oil and generated approximately 2,929 metric tons of sludge. Others in the order are; Saudi Arabia $(10,050,000$ barrels) which also produces 2,871 metric tons of sludge, United State of America $(9,415,000$ barrels) which produces 2,690 metric tons of sludge. China (4,278,000 barrels) and Iraq (4,054,000 barrels) follows with their respective sludge generation of 1222 and 1158 tons/day respectively. Figures $2 \mathrm{a}$ and $2 \mathrm{~b}$ below show the barrels of crude oil production and the associated sludge generation respectively for the various oil producing countries.

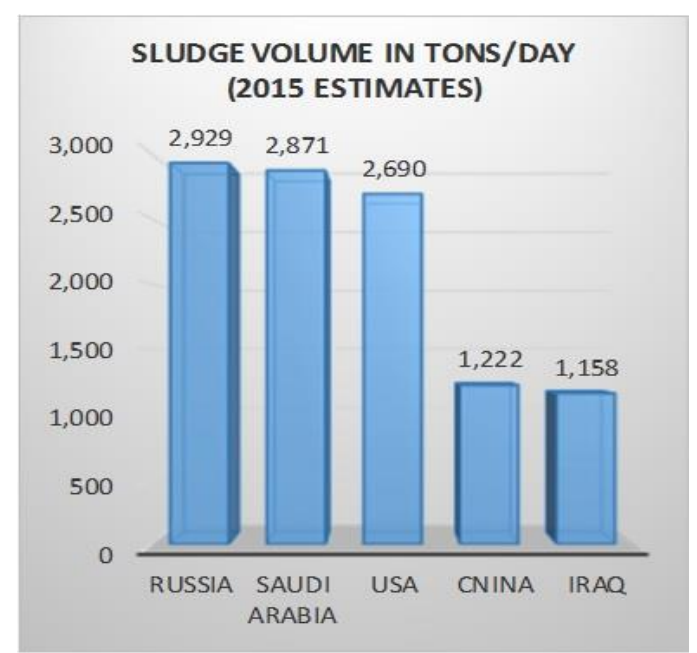

Fig-2b: Associated Sludge Production from 5 Top Oil Producing Countries Information Modified from the World Fact Book-Rank Order

crude per day and with sludge generation of 0.0063 and 0.0014 metric tons respectively. Although, Taiwan is registered among the least crude oil producing countries, the country produced as much as 14 more barrels of crude oil per day than Tajikistan, making it the highest among the world least oil producing country and so has some significant volume of sludge ( 0.056 tons) generation daily. This is represented in figures $3 \mathrm{a}$ and $3 \mathrm{~b}$ below. 


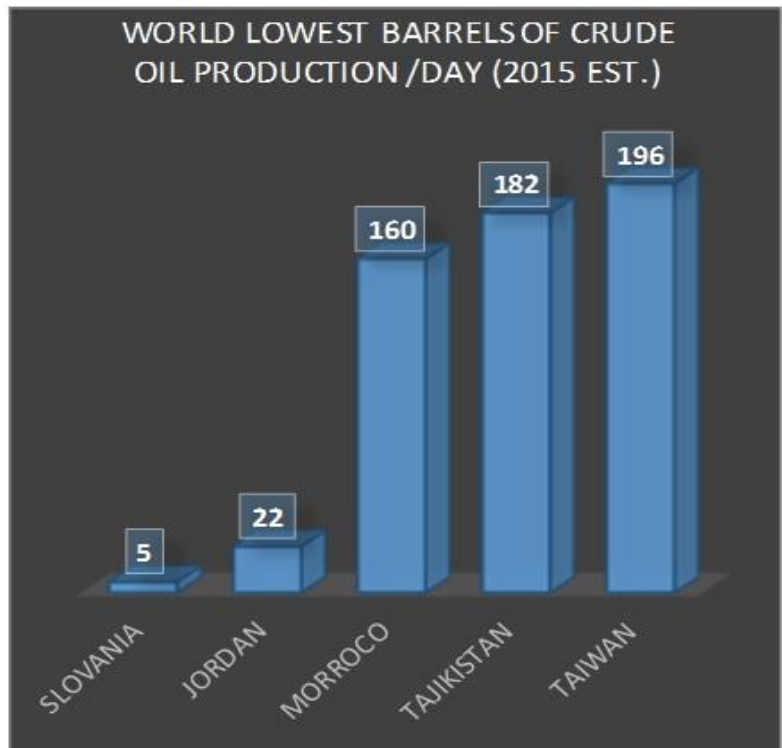

Fig-3a: Estimated Crude Oil Production in 2015 for the last Five Oil Producing Countries Information Adopted from the World Fact Book Rank-Order

Four countries within the West Africa region namely Nigeria, Ghana, Ivory Coast and Niger were also captured in the world fact book rank order list of crude oil producing countries in 2015. On the list, Nigeria produced the highest

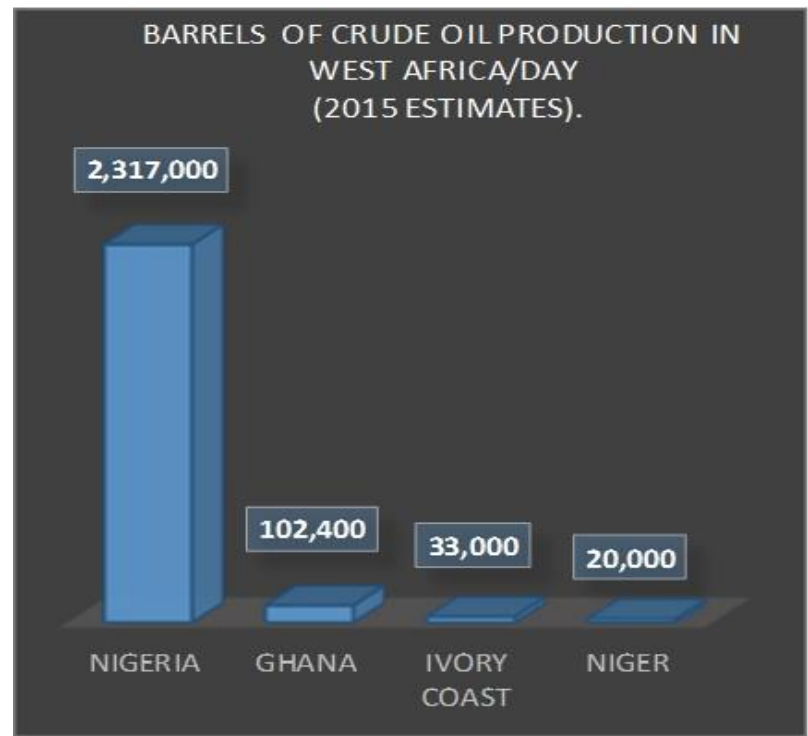

Fig-4a: Estimated World Highest Crude Oil Producing Countries for 2015 in West Africa Information Adopted from World Fact Book Rank-Order

In West Africa, Nigeria produced the highest oily sludge among its members with the volume of 662 tons per day for the year 2015; Ghana is the second highest with 29 tons per day, followed by Ivory Coast 9 tons then Niger 6 tons per day. See figures $4 \mathrm{a}$ and $4 \mathrm{~b}$ below. Though these volumes can be considered low as compared with the world highest oily sludge generating countries, it is substantially high when considering the world lowest sludge generating

\section{SLURDGE VOLUME IN TONS /DAY (2015} EST.) (2015 EST.)

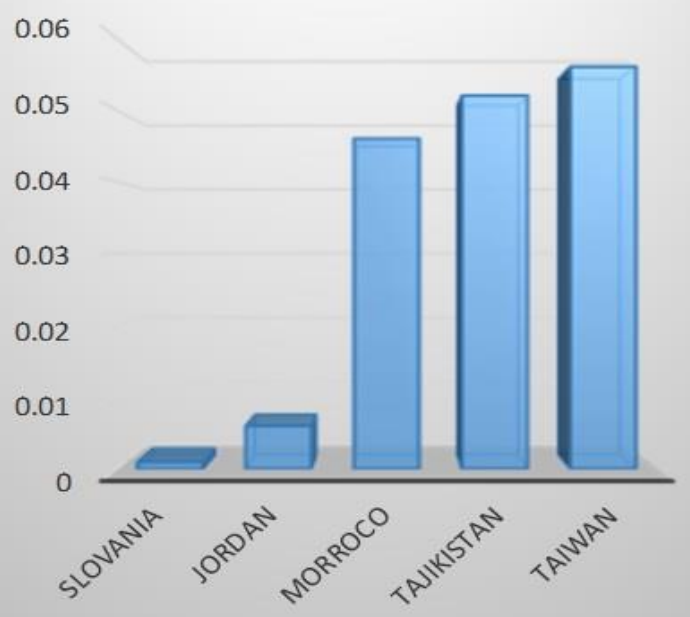

Fig-3b: Estimated Oily Sludge Production in 2015 for the Last Five Oil Producing Countries. Information Modified from the World Fact Book Rank-Order

of 2,317,000 barrels whiles Niger produced the lowest of 20,000 barrels. Ghana and Ivory coast produced 102,400 barrels and 33,000 barrels per day respectively as depicted in the Figures $4 \mathrm{a}$ and $4 \mathrm{~b}$ below.

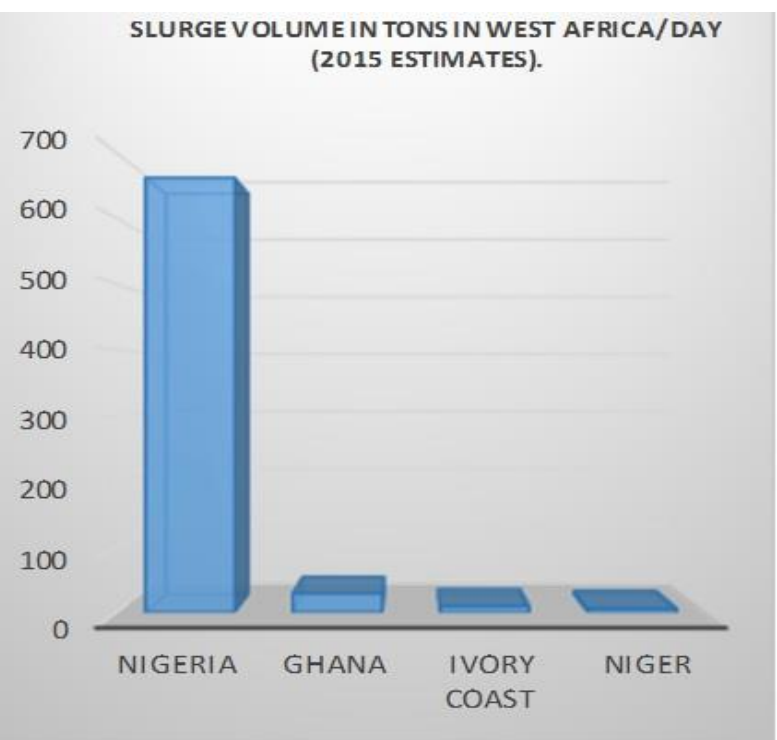

Fig-4b: Sludge Production in 2015 from the Highest Crude Oil Producing Countries in West Africa Information Modified from the World Fact Book Rank-Order

countries. This makes West Africa more susceptible to environmental issues related to sludge management since it lacks resources as a developing region compared to others especially the countries with the highest sludge generation and may have the necessary resource and funds to meet these challenges. Though the results do not project the four West African countries captured in the list as part of the highest nor lowest crude oil producing countries in the year 
2015, their generation of sludge is of concern as indicated by [6]. This is because, the management of this waste is problematic and requires proper disposal and sufficient treatment in order not to pose serious threat to the environment and health [10, 14].

Oily sludge is gotten from crude oil production and processes, worldwide highest crude oil producers per day will automatically generate high volumes of sludge as seen from the Figures $2 \mathrm{a}-2 \mathrm{~b}, 3 \mathrm{a}-3 \mathrm{~b}$ and $4 \mathrm{a}-4 \mathrm{~b}$ above. Russia tops the generation of sludge with 2,929 tons per day and Iraq the least with 1,158 tons per day among the five highest crude oil producing countries. Saudi Arabia generates 2,871 per day whilst USA and Iraq generates 2,690 tons and 1,222 tons respectively.

Countries with low crude oil production per day generates low volumes of sludge. Slovenia generates approximately 0.001 tons of sludge daily compared with Russia which generates as high as 2,929 tons per day; clearly Russia grapples with more challenges in the management of oily sludge as according to [6], best management practices in the industry is nonexistent. However, [16, 24], rather indicate that the lack of willpower and desire to tackle the issue head on is what has resulted in the marginal improvement in the management of this waste though possible solutions and resources exist. Current management practice has therefore been the storing of these wastes in pits, marshes or open earth pool for many years. These techniques cause high levels of contamination of the storage area and its environs. This has now become a prime concern [15]. Countries with low crude oil production per day generate low volumes of sludge. These countries will most likely have low environmental impacts from sludge production.

\subsection{Uses of Oily Sludge}

Sludge have been used for road construction [4]; for the land treatment after it has been pretreated [17]. It has also been found to possess thermal valuable substances and produces 3,900 Kcal per a $\mathrm{Kg}$ of oily sludge [12]. Again, [26] have observed that heavy metal concertation below limits can enhance metabolism of microorganism due to the increase in catalytic activity.

\subsection{Some Problems Relating to Oily Sludge}

Sludge disposal on land has prevented the vegetation growth. Heavy metals in sludge causes biodegradation at the places where land is covered by vegetation [9, 22]. The result of a study conducted by [2] to find the effect of crude oil contaminated soil on cowpea seedlings shows that the crude oil induced an environmental stress on the seedlings because of the rise in free sugar, total protein and amino acids and decreased the chlorophyll content of the leaves. [18], have also shown that the formation of sludge in tanks reduces the effective volume of the storage tanks and accelerates corrosion. He further noted that the accumulated layer at the bottom of the tank can become denser with time and becomes difficult to clear when cleaning the tanks. This will demand cost intensive technology in maintaining the tanks. High volume of Total Petroleum Hydrocarbon (TPH) and heavy metals are potential sources of contamination to the site of disposal of the oily sludge [3]. This has the potential of leaching into the water table /aquifer as well as water bodies with substantial effects on aquatic and human life.

\subsection{Management of Oily Sludge}

Methods of treatment available for sludge management include land farming, incineration solidification/stabilization, solvent extraction, ultrasonic treatment, pyrolysis, photo catalysis, chemical treatment and biological degradation [13, 24, 25]. However, according to [6] sludge management cannot apply traditional methods of treatment and disposal. It cannot for instance, be incinerated as it contains too much oil and water making it almost impossible for any means of thermal mode of treatment. [6], further indicates that Filtering is also impossible because its solid content is high and any attempt at filtering will clog the filtration system. Its high oil, solids, BOD and COD content also makes it impossible to be pumped into treatment plant. Again, [6] suggests that an appropriate and environmentally friendly solution to the sludge management is recycling but the treatment technology can be mainly grouped under physical, chemical and biological remediation.

\subsection{Land Farming as a means of Sludge}

\section{Management}

This is a form of insitu approach where the untreated sludge is transferred from crude tanks to plots of land located within the terminal facility. Here, the plot is constructed in the form of series of engineered cells made of concrete to prevent the material from being released into the environment. It is lined by a heavy-duty membrane-PVC and clay surrounded by isolated waste water system. This helps for the transferred sludge to be mixed with natural soil, turned and watered on routine basis. This process has been found by Bradley (2002) to promote microbial digestion of the hydrocarbon content. Thus, resulting in an inadvertent dilution of the technologically enhanced concentration of the heavy metals and the radioactivity.

Solvent extraction has also been found to be the most suitable and widely used sludge management method as it is the most efficient and cheaper way to separate Petroleum hydrocarbon from petroleum sludge [21]. For this method, valuable hydrocarbons can be recycled back into the fuel cycle to compensate for part of the treatment cost while the residue containing solid particles, water and heavy metals are treated [20].

\section{CONCLUSION}

Oily sludge management is a major challenge to industry players and stakeholders in the oil industry. This paper reviewed from a wider databases and literature concerning 
the current practices in oily sludge management and the potential environmental consequences. It was found that almost all oily sludge is disposed of in a manner that eventually ends up as piles in the environment and there is no indication currently that this practice could stop. Enough attention has been given to technologies for managing oily sludge to make it less harmful to the environment. In order to minimize the quantities and also make it more environmentally friendly, recycling and recovery have been viewed as an acceptable and sustainable management technique for the oily sludge. This is because the practice will help to reduce the treatment cost and its associated environmental effects. It also has the capacity to reduce the volume of residual waste that will be available for disposal and conserve land designated for landfilling.

\section{REFERENCES}

[1]. Aburahman H, Rosli N and Yunus M (2006) "A Continuous Microwave Heating of Water-in-oil Emulsions: An Experimental Study" Journal of Applied Science" Vol. (6) No. (8): 1868-1872, 2006.

[2]. Achuba FI (2006) "The effects of sub lethal concentration of crude oil on the growth and metabolism of cowpea (rigna unguiculata) seedlings" Environmentalist vol. (26):17-20, 2006.

[3]. Adeniyi A and Afolabi J (2002) "Determination of total petroleum hydrocarbons and heavy metals in soils within the vicinity of facilities handling refined petroleum products in Lagos metropolis" Environment International Vol. (28) No. (1): 79-82, 2002.

[4]. Al-Futaisi A, Jamrah A, Yaghi B, et al. (2007) "Assessment of alternative management techniques of tank bottom petroleum sludge in Oman" Journal of Hazardous Materials Vol. (141) No. (3): 557-564, 2007.

[5]. Ayotamuno MJMJ, Okparanma RN, Ogaji SOT, et al. (2007) "Bioremediation of a Sludge containing Hydrocarbons" Applied Energy Vol. (84) No. (9): 936-943, 2007.

[6]. Badrul I (2015) "Petroleum sludge, its treatment and disposal: a review" International Journal of Chemical Sciences Vol. (13) No. (4): 1584-1602, 2015.

[7]. Bipin K and Raj Mohan B (2013) "Petroleum Refinery Oily Sludge, The Quantitative and Qualitative Analysis of its Composition" Indian Stream Research Journal Vol. (3) No. (10): 1-6, 2013.

[8]. BP (2015) "BP Energy outlook 2035" London, United, Kingdom.

[9]. Businelli D, Massaccesi L, Said-Pullicino D, et al. (2009) "Long-term distribution, mobility and plant availability of compost-derived heavy metals in a landfill covering soil" Science of the Total Environment Vol. (407) No. (4): 1426-1435, 2009.

[10]. Da Rocha ORS, Dantas RF, Duarte MMMB, et al. (2010) "Oil Sludge Treatment by photocatalysis applying black and white light" Chemical Engineering Journal Vol. (157), 80-85, 2010.

[11]. Da Silva LJ, Alves FC, de França FP (2012) “A review of the technological solutions for the treatment of oily sludge from petroleum refineries" Waste Management and Research Vol. (30) No. (10), 1016-1030, 2012.

[12]. Hu G, Li J, Zeng G (2013) "Recent development in the treatment of oily sludge from petroleum industry: A review" Journal of Hazardous Materials Vol. (261), 470-490, 2013.

[13]. Liu J, Jiang X, Zhou L, et al. (2009) "Pyrolysis treatment of oil sludge and model free kinetics analysis" Journal of Hazardous Materials Vol. (161), 1208-1215, 2009.

[14]. Mater L, Sperb RM, Madureira L, et al. (2006) "Proposal of a sequential treatment methodology for the safe reuse of oil sludge contaminated Soil" Journal of Hazardous Materials Vol. (136) No. (3), 967-971, 2006.

[15]. Mazlova E and Meshcheryakov S (1999) "Ecological characteristics of oil sludges" Chemistry and Technology of Fuels and Oils Vol. (35) No. (1), 49-53, 1999.

[16]. Mrayyan B and Battikhi MN (2005) "Biodegredation of total organic carbon (TOC) in Jordanian Petroleum Sludge" Journal of Hazardous Materials Vol. (120), 127134, 2005.

[17]. Pazoki M, Abdoli M, Karbasi A, et al. (2012) "Removal of nitrogen and phosphorous from municipal landfill leachate through land treatment" World Applied Sciences Journal Vol. (20) No. (4), 512-519, 2012.

[18]. Pereira A, Zuim F, Lucas G, et al (2014) "Effect of inorganic solids content in petroleum samples on sludge formation and accumulation" Brazilian Journal of Petroleum and Gas Vol. 8 No. (1), 33- 47, 2014.

[19]. Pinheiro B, and Holanda J (2009) "Processing of red ceramics incorporated with encapsulated petroleum waste" Journal of Materials Processing Technology Vol. (209) No. (15), 5606-5610, 2009.

[20]. Raab A and Feldmann J (2003) "Microbial transformation of metals and metalloids" Science Progress Vol. (86) No. (3), 179-202, 2003.

[21]. Taiwo E and Otolorin J (2009) "Oil recovery from petroleum sludge by solvent extraction" Petroleum Science and Technology Vol. (27) No. (8), 836-844, 2009.

[22]. Thavamani P, Malik S, Beer M, et al. (2012) "Microbial activity and diversity in long-term mixed contaminated soils with respect to polyaromatic hydrocarbons and heavy metals" Journal of Environmental Management Vol. (99), 10-17, 2012.

[23]. Wang X, Wang Q, Wang, S, et al. (2012) "Effect of bio stimulation on community level physiological profiles of microorganisms in field-scale bio piles composed of aged oil sludge" Bioresource Technology Vol. (111), 308-315, 2012.

[24]. Xu N, Wang W, Han P et al. (2009) "Effects of ultrasound on oily sludge deoiling" Journal of Hazardous Materials Vol. (171) No. (1), 914-917, 2009.

[25]. Yan P, Lu M, Yang Q, et al. (2012). “Oil recovery from refinery oily sludge using a rhamnolipid biosurfactant producing pseudomonas" Bioresource Technology Vol. (116), 24-28, 2012.

[26]. Zukauskaite A, Jakubauskaite V, Belous O, et al. (2008) "Impact of heavy metals on the oil products biodegradation process" Waste Management and Research Vol. (26) No. (6), 500-507, 2008. 